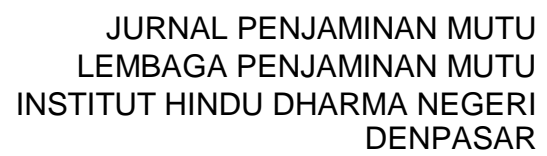

JURNAL PENJAMINAN MUTU

LEMBAGA PENJAMINAN MUTU

INSTITUT HINDU DHARMA NEGERI

DENPASAR

Volume 6 Nomor 1 (2020)

ISSN : 2407-912X (Cetak)

ISSN : 2548-3110 (Online)

http://ejournal.ihdn.ac.id/index.php/JPM

\title{
IMPROVING TEACHER'S PROFESSIONALISM TO INCREASE THE QUALITY OF HINDU RELIGIOUS EDUCATION IN SCHOOL
}

\author{
By \\ Ni Nyoman Perni ${ }^{1}$, Hary Yati Paramitha ${ }^{2}$ \\ ${ }^{1}$ Universitas Hindu Negeri I Gusti Bagus Sugriwa Denpasar \\ ${ }^{2}$ Pasraman Prakam Wyata Dharma Selong, Lombok Timur \\ ${ }^{1}$ nyomanperni80@gmail.com
}

diterima 04 September 2019, direvisi 13 Januari 2020, diterbitkan 29 Pebruari 2020

\begin{abstract}
Abstrak
Penelitian ini bertujuan untuk menganalisis peningkatan profesionalisme guru untuk meningkatkan mutu pendidikan agama Hindu melalui efektivitas dan kreativitas pola interaksi di sekolas. Sekolah sebagai pendidikan formal merupakan lembaga yang memiliki kewajiban untuk membentuk peserta didik menjadi pribadi yang berkarakter luhur. Lembaga pendidikan ini seyogyanya dapat membekali siswanya dengan berbagai nilai, sikap, serta kemampuan dan keterampilan dasar yang cukup kuat sebagai landasan untuk menjalani kehidupan yang sebenarnya di masyarakat. Pribadi yang berkarakter luhur ini dibentuk melalui pendidikan agama Hindu yang dilaksanakan secara berkelanjutan di semua jenjang pendidikan. Agar pendidikan agama Hindu ini maтрu mewujudkan tujuan pendidikan nasional yakni mengembangkan potensi peserta didik agar menjadi manusia yang beriman dan bertakwa kepada Tuhan Yang Maha Esa, berakhlak mulia, sehat, berilmu, cakap, kreatif, mandiri, dan menjadi warga negara yang demokratis serta bertanggung jawab, maka peningkatan mutu pendidikan agama Hindu wajib dilaksanakan, dimana salah satunya dengan meningkatkan efektivitas pola interaksi dalam pembelajaran di sekolah.
\end{abstract}

\section{Kata Kunci : Peningkatan Mutu, Pendidikan Agama Hindu, Pola Interaksi dan Pembelajaran.}

\begin{abstract}
This study aims to analyze the improvement of teacher professionalism to improve the quality of Hindu religious education through the effectiveness and creativity of interaction patterns in schools. School as a formal education is an institution that should shape students to be individuals with noble character. This educational institution should be able to equip its students with a variety of values, attitudes, and abilities and a strong enough basic skills as a basis for living a real-life in society. A high character person of Hindu religious education are carried out continuously at all levels of education. Hindu religious education can realize the goals of national education which is to
\end{abstract}


develop the potential of students. Later on, there are expected to become human beings who believe in and fear God Almighty, have noble, healthy, knowledgeable, capable, creative, independent, and be democratic and responsible citizens. Furthermore, the improvement of the quality of Hindu religious education must be implemented by increasing the effectiveness of learning interaction patterns at schools.

\section{Keywords: Quality Improvement, Hindu Religious Education, Patterns of Interaction and Learning.}

\section{INTRODUCTION}

Schools as formal educational institutions should be able to equip students with a variety of values, attitudes, and abilities and basic skills that are strong enough as a basis for completing education at the next level. One of the basic skills that absolutely must be possessed by every student is a skill in behavior including the cultivation of noble character education from an early age. Education as the foundation of national education plays a very important role in preparing quality human resources to face the era of globalization. Almost all education experts agree that education is very important, because as a foundation for the development of personality, attitudes, and behavior, the inculcation of ethical and moral values, and physical, mental, and insight development. Hindu religious education contains several very important aspects given to students, especially from the basic level, namely personality, attitudes, and behavior, ethical and moral values which are the crystallization of good values from a person's or human behavior.

According to Sai (Setyaningsih, 2019), 'education' comes from the Latin word 'Educare', showing the collection of various worldly facts, so Educare is an attempt to display what is latent in humans. Education is used for livelihood, whereas educare is used for living. Education is used to make a living (Jivanopadhi), educare is used to achieve the goal of life (Jivitha paramavadhi).

According to The American Encyclopedia (Titib, 2003), the notion of education is a process of a person getting knowledge, understanding, developing attitudes or skills.

All of that must be intentionally transformed from one generation to the next. This education is formally taught to students in school, can also be taught informally by students' parents and the community, because children are more at home than at school. The learning process has begun since the child is in the womb because the child has received responses or sounds since still in the mother's womb until they were born. A great educated perfomed by parents until the age of school which is 7 years old, and school in basic education. When the child enters this formal level of education, the child usually starts interacting and occurs or other psychological concepts and attitudes are formed. The role of parents and the community where the child first interacts will continue to carry over.

After entering the formal education level, it becomes a very important teacher's task to form a good student personality. Teachers, especially Hindu Religion teachers be the foundation for the child for themental formation. A teacher is required to change learning with his art so that students do not get bored. Hindu religious teachers are considered as people who play an important role in shaping the mental and moral attitude of children with the teachings of religious literature being taught. Creating pleasant conditions students will learn and continue to learn, if the learning conditions are made pleasant, comfortable, and away from behaviors that hurt students' feelings. Today the era of globalization and information is reaching everyone, including Indonesia. For the Indonesian people, there are many 
benefits derived from it, but the slightest will have a negative impact, both on the world of politics, economy, social culture and on one's behavior. Therefore, to drive the personality and identity of the Indonesian people are not eroded by outside influences, one effort to counteract and overcome, Hindu religious education, especially character, ethics, and morals must be taught to all children as early as following the purpose of education.

National education aims to develop the potential of students to become human beings of faith, be devoted to God Almighty, have a good character, be healthy, skilled, independent and become democratic citizens and be responsible for the principles in that goal. The goal is education has a role to develop human potential to form competencies in themselves, to be intelligent and noble character. Here, for harmonious interaction to occur, a positive attitude and morals are needed. Moral is a doctrine of good and bad that concerns human behavior and actions (Sudharta, 2001: VII).

According to Widiasih (2016) to be a professional Hindu teacher, it will be very necessary to understand the teachings of Hinduism as a whole and not in pieces and its delivery must be adjusted to the era development. One way to understand Hinduism as a whole can be done through historical approaches, libraries, teaching structures, supporting cultures and the dynamics of life with the science and technology media as its supporting media. One must preserved confidence attitude without being influenced by others. The influence of others is an education that directs students to always have a positive behavioral impact useful for themselves, groups and society. Considering Hindu religious education is very important for human life, the education needs to be developed. There are attitudes of human in opposite to Hindu teachings as it is caused by the theorithical style of formal education, not in morality and ethics in practice that can change human behavior to be mature. The failure of Hindu education and teaching can be seen from the behavior of students who are not polite to talk with older people, with teachers at school or with their parents at home.

The foregoing is contrary to the image of the Indonesian people who are well known in international world as a polite and cultured society. People with a polite culture and noble character, moral values, human values, and social values seem to have shifted away from the general norms that are feasible in society. It can develop Hindu religious education in three educational centers, namely family, school and community. The development of the Hindu religious education center will cause imbalance and even stagnate the development of noble character to students. To create that, various efforts are needed, the efforts are guidance,, teaching, and training. It carried all efforts out with the aim that early students have good habits so that teachers and parents play an important role in achieving educational goals and national education goals. The role of teacher is not only in teaching and learning activities (KBM) but how the formation of attitudes, behavior, in the form of character education, so that they truly understand and practice all the commands and advice of teachers in schools and parents in the family environment.

\section{METHOD}

To improve teacher professionalism for the quality of Hindu religious education in schools, the author used descriptive qualitative research. It was chosen because the data based on the facts in the field, arranged systematically following what it is, revealing problems that have occured, and reviewed and presented accordingly to obtain a complete picture regarding the problem. In this study, it used several data collection techniques: (1) Observation; (2) Interview; and (3) Literature Study; and (4) Documentation. Through these data collection techniques, researchers determine informants in two ways, namely purposive sampling. 


\section{RESULTS AND DISCUSSION} 1. Hindu Religious Education Concepts

The discussion on Hindu religious education will not be separated from the general conception of education. According to Muhibbin (1999) education can be interpreted etymologically as "Education comes from the word educator then gets the prefix " me "(in Bahasa Indonesia), so that to educate means to maintain and provide training needed teachings, guidance, leadership regarding morals and intelligence of the mind" So education is not only emphasized mind intelligence or intelligence alone, but more than that it is the change in behavior through the learning experiences provided. Meanwhile, according to Purwanto (1998) education is all efforts of adults in the association of children to lead the physical and spiritual development towards maturity. Ngalim stressed that education applies for relationships between adults and children.The relationship between adults cannot be called relationship in the educational process, because adults accept and are responsible for what it contains.
Likewise, the relationship between children cannot be said relationship in the educational process. Even though it is often seen in the association between these children, a child who stands out can influence other children but the power over his peers is not the power of education because that power is not aimed at an educational goal that he is aware of or is not done intentionally. Education plays an important role in life and can guarantee the development and continuity of a nation. Education is a deliberate effort either directly or indirectly to help children in their development reach adulthood. The educational process is formal, informal and non-formal. Education has two functions:

a. Social Function education must help each individual to be a member of a successful society by teaching him several past and present experiences.

b. Individual functions, it tasks education with helping and fostering individuals to enjoy a better, more satisfying and more successful life by preparing the individual to handle new good experiences.

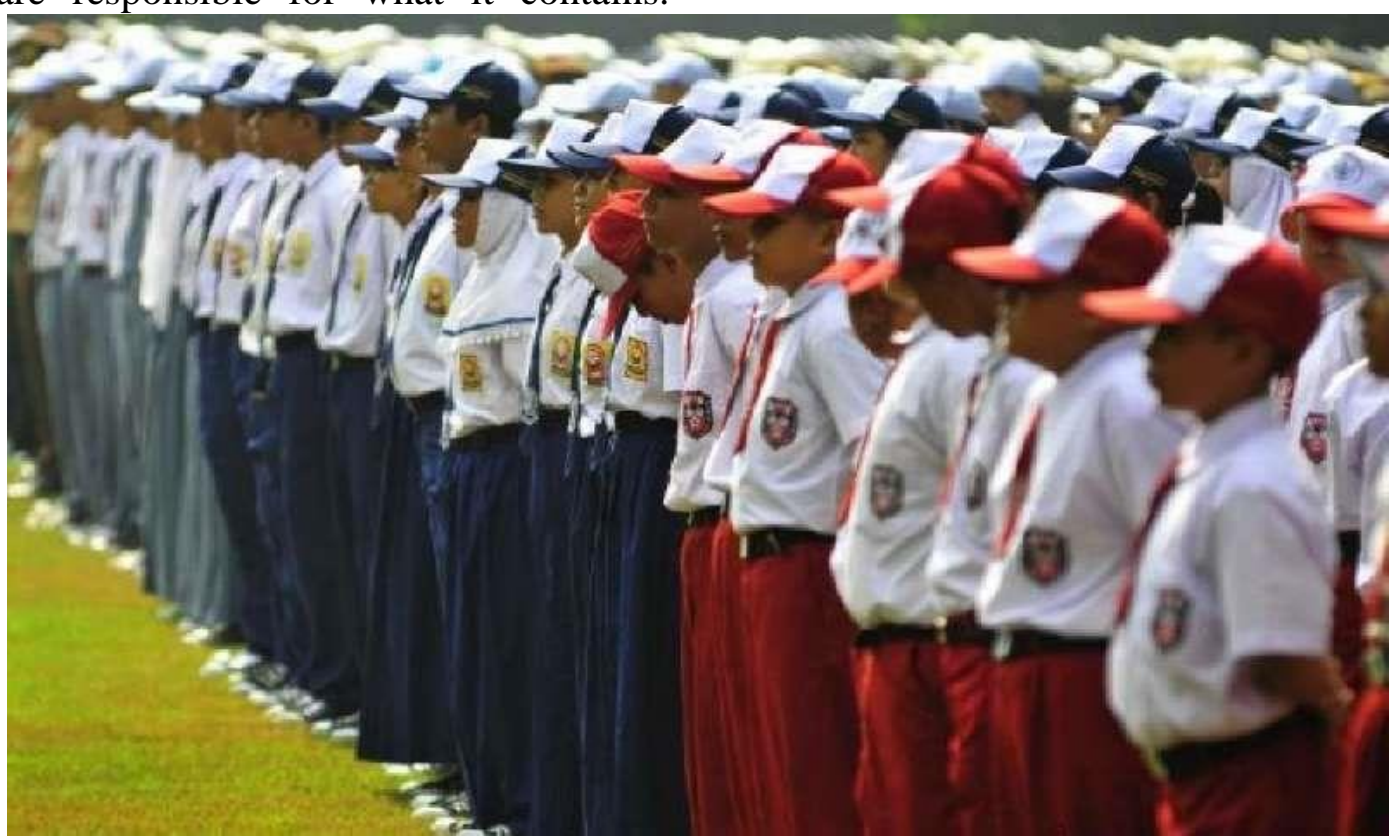

Figure 1. Students Are Lining Up (Source : https://www.keluargasamawa.com/ tujuan-dan-fungsi-pendidikan-nasional)

Education is not merely aimed at teaching subjects, but it educates, raises and develops the child's personality. Education is a manifestation of perfection that has existed in humans. So it is an integrated and harmonious development of the human 
personality. The intended education is to explore personality potentials that are naturally within human beings. Lifelong education is not just for life. Education should be a process of development of the human personality, the blossom of noble human values towards perfection and the realization of good values. Humanitarian education is not a separate subject but must be the essence of all extra-curricular subjects, curriculum, and activities.

Education teaches us language and knowledge, but there is no lesson on how we can live quietly, happily or in peace between ourselves and with others. Therefore, Mahatma Gandhi said "Education without character is useless, even very dangerous. He even stated that education should lead to humanity. Education must shape and develop a batter character. In short, education must be fully human, not only related to intellectual education but also the subtlety of mind and inner discipline.

About Hindu Religious Education, Punyatmaja, (1994: 12) asserted that Hindu religious education provides guidance in life and educating the public, how should stand, act or behave so as not to conflict with dharma, manners, ethics, and religion. Religion can perfect humans in improving life both materially and spiritually. Hindu religious education is the norms that guide people to always do good for the achievement of peaceful harmony and to form a human who starts and always acts of devotion to Ida Sang Hyang Widhi Wasa with devotion and sacrifice under the teachings of Hinduism. Hindu religious education is a teaching on moral education that is guided according to the instructions of religious teachings to function as an observation factor that will become a person's salvation. So religious education is the guidance given to someone to show the development of manners, it is needed to raise the love of religious teachings and willing to act as the teachings. Hinduism teaching material is sourced from the Vedas.

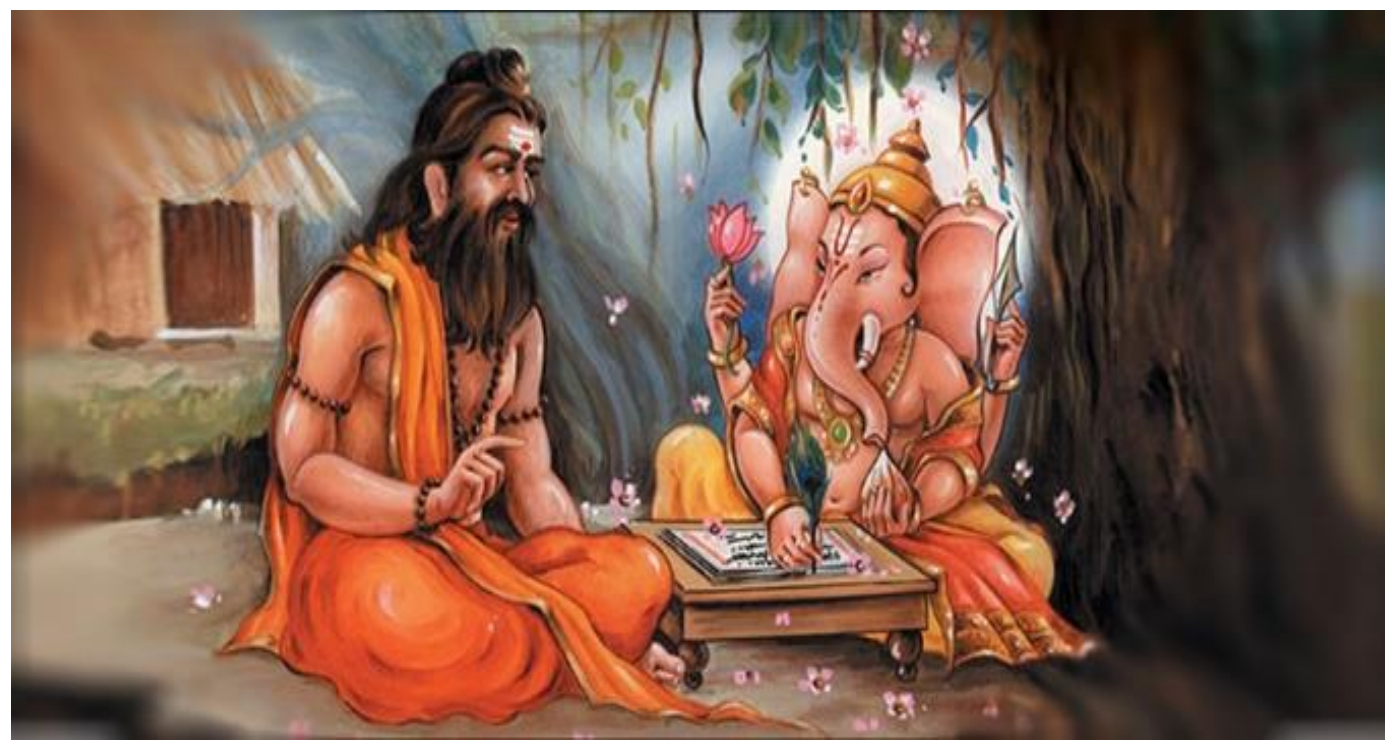

Figure 2. The Vedic Source Of Hinduism (Source : https://www.komangputra.com/weda.html)

According to Vishvanath (Setyaningsih, 2019) the direction and purpose of education is to transform educational values so that students have a complete personality. Commitment to education brings children to be aware of their authenticity (self-realizing). What is said as it leaves education today in us after we forget everything. So what remains after everything is forgotten? Good character. Without good character, education is useless. 
Formation of good character in students as Bhagawan Sri Sathya Sai Baba (Setyaningsih, 2019) states:

\section{The aim of knowledge is wisdom \\ The aim of civilization is perfection \\ The aim of wisdom is freedom and \\ The aim of education is a good character}

According to Titib, the aim of Hindu religious education has been formulated by the Parisada Hindu Dharma Indonesia Center through a unity interpretation seminar on aspects of Hinduism (Budiadnya, 2019):

a. Embedding the teachings of Hinduism into beliefs and a foundation for all activities of Hindus in all their lives.

b. The teachings of Hinduism direct the growth of Hindu social governance to be in harmony with Pancasila, the basis of the Republic of Indonesia.

c. Harmonizing and balancing the implementation of parts of the teachings of Hinduism in society between tattva (tatwa), moral (susila) and ceremonies.

d. To develop a harmonious life between people of various religions.

\section{Effectiveness of Interaction Patterns in Learning Hindu Religious Education in Schools}

The pattern applied in teaching and learning interactions is one effort to achieve educational goals. The purpose of education will not be achieved if the interaction of teaching and learning never takes place in education. Teachers and students are two important elements directly involved in education. Interactions carried out for teachers to use various patterns. The teacher still uses the direct learning model so students assume that the teacher will tell students what they need to know (Vrihastien, Widodo, \& Ayuningtyas, 2019).

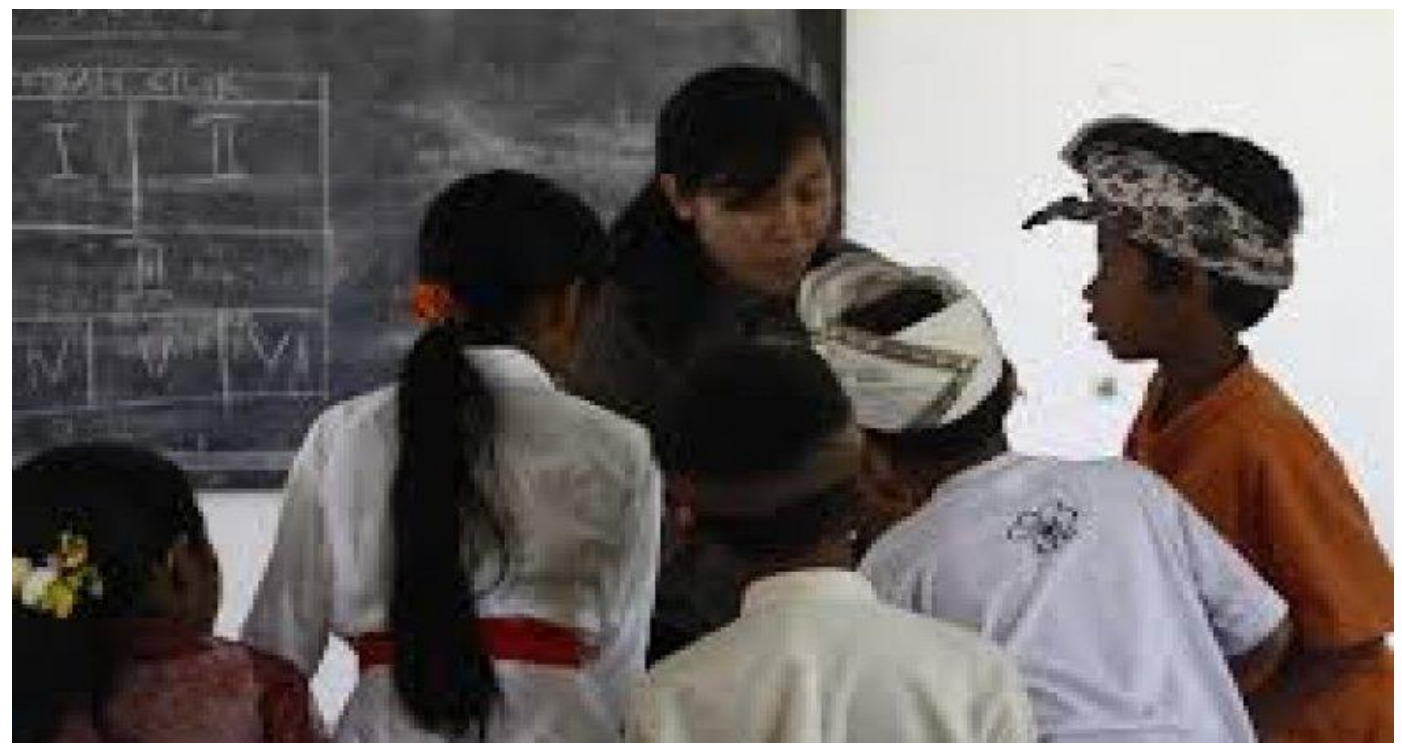

Figure 3. Guru Bhakti Road to Happiness

(Source : https://phdi.or.id/artikel/guru-bhakti-jalan-menuju-kebahagiaan)

Children with analytic learning styles are better suited to self-study and then join study groups. They also have difficulty in learning because they only focus on one thing. The best way to overcome this is to create a structured learning schedule so that the learning goals you want to achieve are clear. The right learning method is to consistently do or do the task under the daily schedule he made.

\section{Student-Teacher Pattern}

This pattern is called communication as (one-way) action. Communication as an action or a direction puts the teacher as action and students as recipients of the action. Active teachers and passive students. In this pattern, the teacher uses one method, the lecture method. The lecture method is a method in education and teaching in which the way of conveying the understanding of 
subject to students is carried out orally by the teacher in the classroom. The role of the teacher or student is different, namely the teacher especially in speaking and explaining actively, while the student listens and follows carefully and makes notes on the subject matter that is explained by the teacher. The teacher in explaining the subject matter must see or understand the sub-topics to be explained. Thus the method used is also appropriate so that it can achieve learning outcomes. In explaining this material there will be an interaction or communication that exists between the teacher and students because without an interaction or good communication, learning success will be difficult to achieve. The teacher according to Yamin (2007) can do the lecture method:

a. To provide direction, instructions at the beginning of the lesson.

b. Limited time, it will deliver a lot of material or information

c. Educational institutions have a few teaching staff, while the number of students is large.

Practicum activities undertaken must be adapted to the existing curriculum through a scientific approach so that students can know the procedures, processes and methods in scientific work. Students need to be involved in a variety of activities that are appropriate and need to find appropriate ways to assess performance in activities and can provide feedback and encourage students to build understanding of scientific concepts to develop thinking, reasoning, discussion, and scientific skills that can support students in solution to problem (Hamidah, Sadikin, Sanjaya, Aina, \& Natalia, 2019). Limitations of the lecture method are:

a. Student success is immeasurable

b. Student attention and motivation are difficult to measure

c. Student participation in lessons is low

d. Less focused material

e. Talks often digress.

\section{Teacher-Students-Students-Teacher Patterns}

In this pattern there is feedback (feedback) for the teacher, there is no interaction between students (communication as interaction). Communication as interaction or two-way communication, the teacher and students can acts as the giver of the action or the recipient of the action. In this interaction, a teacher uses the lecture and question and answer method. Question and answer method is a method of teacher asking questions while students answer about material that they want to obtain. Or conversely, students ask questions to the teacher from the explanation of the material that is not yet understood by students and the teacher provides a comment or explanation as an answer to the question earlier.

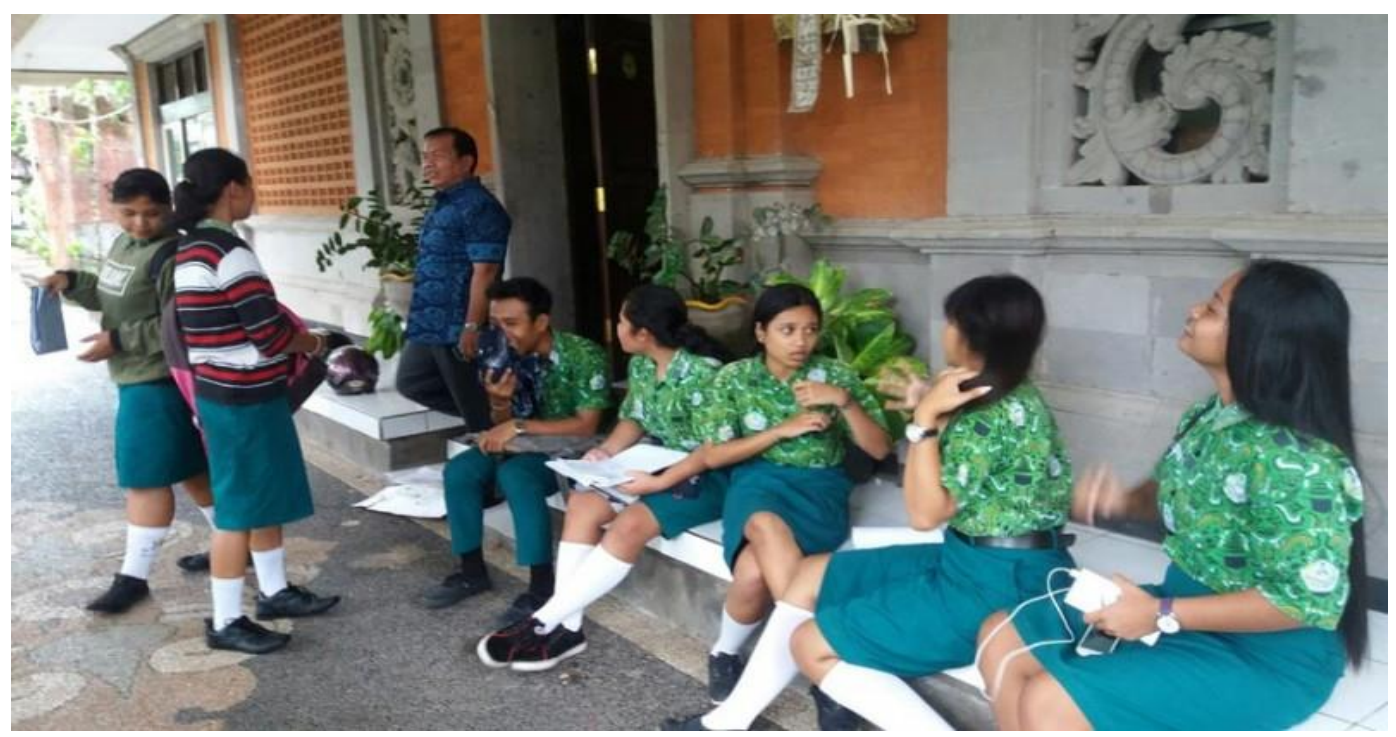

Figure 4. Every Saturday, Students Are Required To Speak Balinese (Source : https://www.nusabali.com/berita/3119/tiap-sabtu-wajib-berbahasa-bali) 
Weaknesses in the question and answer method can cause deviations and the main problem. Let alone, if students give answers or propose that can cause new problems and deviate from the main subject.

\section{Teacher-Students-Students Patterns}

In this pattern it is the opposite for teachers, students learn from one another. Communication occurs not only between the teacher and students. It demands students to be more active than teachers, and teachers can function as a source of learning for students. Here, the teacher uses the discussion method. The discussion method is a group activity in solving problems to conclude. According to Yamin (2007) states the method of discussion states the interaction between students or students and teachers to analyze, solve problems, explore or debate certain topics or problems. The discussion is always directed at solving problems that give rise to various opinions and finally, conclusions can be drawn by members of the group. So the teacher as a giver of ideas and as ideas of problems (discussion material) while students as seekers out of the discussion material. According to Yamin (2007) this discussion method is used if:

a. Provide material, topics, or issues to be discussed,

b. Mention materials to be discussed or give special studies to students before holding a discussion.

c. Assign students to explain, analyze, and summarize.

d. Baffling the discussion does not give a speech

e. Be patient with slow groups discussing.

f. Be wary of groups that are confused or walk non-fixed.

g. Train students in respecting the opinions of others.

This discussion method is appropriate if:

a. Students are in the intermediate or final stages of the learning process.

b. Normal lessons or internships. c. Expansion of knowledge mastered by students

d. Learn to identify and solve problems and decide

e. Familiarize students faced with various approaches, interpretations, and various personalities.

f. Facing problems in groups

g. Familiarize students with argumentation and rational thinking.

The discussion method has the following limitations:

a. Take a long time and a few students

b. Requires students to have a sufficient background on the topic or issue being discussed.

c. This method is not appropriate to be used in the early stages of the learning process if new students are introduced to new learning material

d. Apathetic for students who do not normally speak in normal.

\section{Teachers-Students, Students-Teachers, Students-Students Patterns}

In this pattern the optimal interaction between teachers and students and between students and students. Every student in this pattern expresses their opinions on the problems raised by the teacher, as well as between students and other students. In interactions like this, the teacher uses a mixed-method, or a combined method, which is the lecture method, question and answer, and discussion.

Interaction using mixed methods or combined methods for students turned out to show good results. This can be seen from group discussions, both assessments about affective, cognitive, and psychomotor, showing that students in the teaching and learning process are more active in developing ways of learning. Through this method, the students are kneeling more independently, while the teacher acts as a guide in the learning activities. Mixed methods or combined methods can be done by the teacher to:

a. Provide direction, instructions at the beginning of the lesson. 
b. Review past lecture lectures, so students focus again on the type and amount of progress that has been achieved so that they can continue their study.

c. Provide material, topics, or issues to be discussed,

d. Train students in respecting the opinions of others.

Limitations of the mixed method or the combined method as follows:

a. Student success is immeasurable

b. Student attention and motivation are difficult to measure

c. Student participation in lessons is low

d. Take a long time and a few students

e. This method is not appropriate to be used in the early stages of the learning process if it introduces new students to new learning material

Goodness of mixed methods or combined methods, namely:

a. Allow students to express their opinions so that names that are unclear or incomprehensible appear.

b. Knowing the differences of opinion that exist, which can be brought towards a discussion.

The explanation is to facilitate understanding of this combined method can be seen from the interaction of teachers and students, and students with students. The application of Hindu religion learning in schools when viewed from the perspective of constructivist theory seems need to be developed in more depth so that the application of Hindu religious education from an early age can provide meaningful knowledge to each student. Meaningful knowledge that arises because of the learning process needs to be instilled in students so that the child is in school. That is caused by the selection of the right learning model that allows for the growth of critical attitude, and creative, innovative and dynamic in students by applying a habituation model that is understanding the learning process by balancing aspects of knowledge and aspects of religious attitudes of students in a real way.
Multicultural education curriculum can be applied in every level of education through student programs and the process of habituation through daily learning both at school and at home (Karimah, Haryono \& Ahmadi, 2020). The teacher in constructivist learning acts as a person who has the role of empowering all students' potential so that students can carry out the learning process and trying to empower all potentials and means that can help students to form their knowledge. Hindu religious education, which is held in schools, is expected to foster meaningful knowledge in the learning process based on direct experience conducted by students.

\section{CONCLUSION}

Improving the quality of Hindu religious education is inseparable from the role of professional teachers. Therefore, respecting and empowering Hindu religious teachers in educational reform is also obligatory. A professional Hindu teacher is the most important thing for the education system success. Appreciating and empowering Hindu religious teachers must follow the achievements achieved. The pattern of interaction in learning Hindu education in schools is one effort to achieve educational goals. The pattern that can be applied is the teacher-students pattern (oneway interaction), teacher-students-studentsteacher pattern (feedback), teacher-studentsstudents pattern (students learn from each other). Each student has different characteristics and learning styles, therefore every educational implementer must be able to know and understand the characteristics of each student so that learning can run smoothly. Teachers make a lesson plan with method and media driving to effective learning.

\section{REFERENCE}

Budiadnya, P. (2019). Peran Guru Rupaka Daalam Menanamkan Ajaran Agama Hindu Dalam Keluarga Di Kota Surakarta. Kamaya: Jurnal Ilmu Agama, 2(2), 123-142. 
Hamidah, A., Sadikin, A., Sanjaya, M. E., Aina, M., \& Natalia, D. (2019). Workshop Model Pembelajaran Biologi Bagi Guru-Guru MGMP di Kabupaten Tanjung Jabung BaratJambi-Indonesia. DEDIKASI: Jurnal Pengabdian Masyarakat, 1(2), 171197.

Karimah, L., Haryono, H., \& Ahmadi, F. (2020). The Development of Bolokuncoro Interactive Learning Multimedia for Language Literacy of Children Aged 5-6 Years Old. Journal of Primary Education, 9(2), 144-151.

Muhibbin Syah. (1999). Psikologi Belajar. Jakarta: Logos Wacana Ilmu

Punyatmaja, I. B. O. (1994). Cilakrama. Denpasar: Upada sastra

Purwanto, Ngalim (1998). Psikologi pendidikan. Bandung: PT.Remaja Rosdakarya

Setyaningsih. (2019). Peran Pendidikan Agama Hindu Dalam Membentuk Kepribadian Siswa. Widya Aksara, 23(2)

Setyaningsih, S. (2019). Implementasi Pembelajaran Pendidikan Agama
Hindu Dalam Pembentukan Karakter Anak Hindu Di Sekolah Dasar Negeri Surakarta. Cetta: Jurnal Ilmu Pendidikan, 2(2), 297-332.

Sudharta, T. R. (2001). Upadesa Tentang Ajaran-Ajaran Agama Hindu. Surabaya : Paramita

Titib, I M. (2003). Teologi dan Simbolsimbol dalam Agama Hindu. Surabaya: Paramita

Vrihastien, A., Widodo, S. A., \& Ayuningtyas, A. D. (2019). EFEKTIVITAS STUDENT TEAMS ACHIEVEMENT DIVISION DITINJAU DARI PRESTASI BELAJAR MATEMATIKA. AKSIOMA: Jurnal Program Studi Pendidikan Matematika, 8(3), 374-381.

Widiasih, N. N. S. (2016). Meningkatkan Profesionalisme Guru Agama Hindu. Jurnal Penjaminan Mutu, 2(1), 105113.

Yamin, M. (2007). Strategi Pembelajaran Berbasis Kompetensi. Jakarta: Gaung Persada Press. 